\title{
Lignocellulolytic enzymes and bacteria associated with the digestive tracts of Stenochironomus (Diptera: Chironomidae) larvae
}

\author{
R. Koroiva ${ }^{1,2}$, C.W.O. Souza ${ }^{2}$, D. Toyama ${ }^{3}$, F. Henrique-Silva ${ }^{3}$ and \\ A.A. Fonseca-Gessner ${ }^{1}$ \\ ${ }^{1}$ Laboratório de Ecologia de Insetos Aquáticos, \\ Departamento de Hidrobiologia, Centro de Ciências Biológicas da Saúde, \\ Universidade Federal de São Carlos, São Carlos, SP, Brasil \\ ${ }^{2}$ Laboratório de Microbiologia e Parasitologia, \\ Departamento de Morfologia e Patologia, Centro de Ciências Biológicas da Saúde, \\ Universidade Federal de São Carlos, São Carlos, SP, Brasil \\ ${ }^{3}$ Laboratório de Biologia Molecular, Departamento de Genética e Evolução, \\ Centro de Ciências Biológicas da Saúde, Universidade Federal de São Carlos, \\ São Carlos, SP, Brasil \\ Corresponding author: A.A. Fonseca-Gessner \\ E-mail: gessner@ufscar.br
}

Genet. Mol. Res. 12 (3): 3421-3434 (2013)

Received July 6, 2012

Accepted January 22, 2013

Published April 2, 2013

DOI http://dx.doi.org/10.4238/2013.April.2.2

ABSTRACT. We analyzed the digestive activity of the enzymes that digest cellulose and hemicellulose and the bacterial community that is capable of hydrolyzing wood compounds in the digestive tracts of Stenochironomus (Diptera: Chironomidae) larvae, which are miners of decomposing submerged tree and bush branches. Based on quantification of reducing sugars, these larvae have a limited capacity for cellulose degradation but a good capacity for xylan hydrolysis. We isolated 31 types of colonies from two larval morphotypes, of which 19 tested positive for the capacity to hydrolyze at least one of the four substrates that were used as the main carbon source in the culture media. Their woody compound degradation capacity was assessed using colorimetric tests. The bacteria 
were identified by the analysis of the 16S rRNA gene. None of the bacteria were capable of degrading lignin. The genus Pseudomonas had the greatest species richness; Bacillus spp exhibited the greatest capacity for degrading the different substrates, and Sphingobium was found in both morphotypes. Microorganisms participate in the degradation of wood consumed by Stenochironomus larvae. This is the first report of lignocellulolytic bacteria and enzymes in the digestive tracts of mining chironomids.

Key words: Bacteria; Digestive enzymes; Carboxymethyl cellulose; Microcrystalline cellulose; Xylan; Saproxylic larvae

\section{INTRODUCTION}

The presence of lignocellulolytic enzymes and/or microorganisms in the digestive tracts of invertebrates indicates that these organisms have the capacity to use wood as an energy source (Martin, 1983). According to Martin (1983), more than one hundred species of insects belonging to nine orders have cellulolytic activity in their digestive tracts. Despite this apparent diversity, the difficult degradation and low nutritional quality of cellulose lead to the dependence of most xylophagous and phytophagous insects on associative relationships with microorganisms for the use of this resource, especially those insects that use wood as their main food source (Brune, 2006).

There is evidence for the digestion of lignocellulosic material by diverse terrestrial insects such as cockroaches (e.g., Cruden and Markovetz, 1979), termites (e.g., Wenzel et al., 2002), beetles (e.g., Delalibera Jr. et al., 2005), and grasshoppers (e.g., Willis et al., 2010). Among aquatic insects, the orders Trichoptera, Ephemeroptera, Coleoptera, and Diptera have representatives with xylophagous feeding habits. However, the low efficacy of wood degradation among the majority of the organisms cited belies the importance of this resource as a source of nutrition (Martin, 1983).

In the family Chironomidae (Diptera: Nematocera), which is a macroinvertebrate group with a broad distribution and a high abundance and diversity in freshwater environments, the capacity to digest cellulosic compounds is considered low or even nonexistent among insects that collect organic particles (Martin, 1983). With regard to miner insects, there is only one report, based on unpublished (unconfirmed) data, that indicates that the larvae of Xylotopus par are incapable of degrading lignocellulosic materials (Kaufman et al., 1986). Despite microbial participation in the digestive processes of other aquatic insects (e.g., Sinsabaugh et al., 1985), studies addressing the presence of bacteria in the digestive tracts of these larvae have been mainly restricted to the controversial topic of their collaboration as energy source (e.g., Baker and Brandnam, 1976; Pinder, 1986; Johnson et al., 1989).

Some chironomid larvae are capable of completing their development on a diet restricted to bacteria (Pinder, 1986). However, even in environments in which bacteria are sufficiently abundant to meet their dietary needs, chironomid larvae are selective with regard to consumption, and they use other resources such as detritus as an energy source (Johnson et al., 1989). Moreover, the assimilation rate of bacterial compounds may be insufficient for the maintenance of larvae, and there may be a need for other energy sources, as determined for Chironomus riparius (Baker and Brandnam, 1976). 
Even when larvae do not obtain carbon and nitrogen exclusively from microorganisms, the bacterial biomass appears to be important for the provision of specific substances or the chemical modification of detritus (Pinder, 1986), with possible evidence for a bacterial contribution to digestive processes. Rouf and Rigney (1993) assessed the bacterial microbiota in the larvae of Chironomus plumosus, a detritivorous chironomid, over a two-day period; they found differences in the community and density of the bacteria and reported the buildup of bacteria in specific regions of the gut. However, the authors did not report any type of function or interaction between the bacterial communities and the digestive tracts of the larvae. By analyzing different larval instars of $X$. par, Kaufman et al. (1986) found bacteria in a continuous strip on the epithelium of the lumen. The authors raised the hypothesis that these bacteria could contribute to the degradation of wood, but the report about the insufficiency of cellulose degradation in the midgut questioned this possibility.

The description of members of the microbial community in the gut of an insect is considered to be the first step toward understanding the relationships of the structures and functions of commensal microorganisms in host insects. Species of associated cellulolytic bacteria are well established in terrestrial insects (e.g., Wenzel et al., 2002; Delalibera Jr. et al., 2005). However, the use of molecular methods has only recently identified bacteria related to aquatic insects, particularly in the larvae of the genus Tipula (Diptera: Tipulidae) (Cook et al., 2007).

Although independent identification techniques using cultures allow a better characterization of the microbial community, culture isolation techniques with substrates that are present in the natural diet are valuable tools for the identification of microorganisms that assist in the digestive processes of insects (Park et al., 2007).

Considering the limited knowledge about biopolymer degradation capacity and the evidence that bacteria may assist in the digestive processes in the larvae of chironomids, thereby allowing the digestion of wood and its use as an energy source, the aim of the present study was to quantify the specific enzyme activities of cellulase and hemicellulase and to quantify, isolate, and identify possible cultivable lignocellulolytic bacteria associated with the digestive tract of chironomid larvae. Stenochironomus larvae were selected for the present study. This cosmopolitan genus is recognized as a xylophagous miner of tree trunks with morphological adaptations for the colonization of submerged trunks. The current study provides the first evidence of hydrolytic bacteria and enzymes that act on lignocellulosic compounds in the larvae of miner chironomids.

\section{MATERIAL AND METHODS}

\section{Acquisition of the larvae}

Submerged trunks were collected near the headwaters of streams for the acquisition of Stenochironomus larvae, which were sorted based on size and then kept between $0^{\circ}$ and $4^{\circ} \mathrm{C}$ for a maximum of $3 \mathrm{~h}$ prior to dissection.

Because the identification of chironomids is based on adult males, the identification of these species' larvae is difficult. The types of larvae were identified by their morphological characteristics and the location of their origin. Two morphotypes of Stenochironomus larvae were identified: Stenochironomus 1 and Stenochironomus 2. Type 1 larvae were collected from submerged trunks in Fazzari Stream $\left(21^{\circ} 58^{\prime} 09^{\prime \prime} \mathrm{S}, 47^{\circ} 53^{\prime} 04^{\prime \prime} \mathrm{W}\right)$, which is located in a reserve of the Brazilian 
savanna in the city of São Carlos, SP, Brazil. Type 2 larvae were collected from trunks in Galharada Stream (22 $\left.41^{\prime} 40^{\prime \prime} \mathrm{S}, 45^{\circ} 27^{\prime} 36^{\prime \prime} \mathrm{W}\right)$, which is located in an area of mixed rainforest in Campos do Jordão State Park in the city of Campos do Jordão, SP, Brazil.

\section{Enzyme assays}

For the quantification of enzyme activity, the contents of 8 digestive tracts were used to ensure that there was sufficient material for the analyses. The enzyme extractions was according to Oppert et al. (2010). Cellulolytic and hemicellulolytic activities were assessed by the quantification of reducing sugars in a modified 3,5-dinitrosalicylic acid assay. Two substrates with distinct properties were used in the cellulase assay: carboxymethyl cellulose $(\mathrm{CMC})$ [endo- $\beta$-1,4-glucanases (EC 3.2.1.4)] and microcrystalline cellulose (MCC) [endo- $\beta$ 1,4-glucanases (EC. 3.2.1.4), exo- $\beta$-1,4-cellobiohydrolases (EC. 3.2.1.91), and $\beta$-glucosidases (EC. 3.2.1.21)] (Oppert et al., 2010). For the assessment of hemicellulose degradation capacity, a test was carried out with beechwood xylan [ $\beta$-xylanase (EC. 3.2.1.8)], which is a hemicellulosic polysaccharide that is abundant in the cell walls of terrestrial plants.

The enzymes extracted from the insects were then added to 2\% CMC (C5678 Sigma, USA), 2\% MCC (11363, Avicel, Fluka, Ireland), and 1\% beechwood xylan (X4252 Sigma, Germany) that were each suspended in $50 \mathrm{mM}$ citrate buffer at $\mathrm{pH}$ 6.0, which is close to the $\mathrm{pH}$ found in the digestive tracts of chironomid larvae (Frouz et al., 2007). The samples were incubated for $1 \mathrm{~h}$ with the $\mathrm{CMC}$ and xylan substrates and $2 \mathrm{~h}$ with the MCC substrate at temperatures of $50^{\circ}$ and $18^{\circ} \mathrm{C}$ in an adaptation of the method described by Shi et al. (2010). The assay at $50^{\circ} \mathrm{C}$ was based on previous enzyme analysis studies (Oppert et al., 2010; Shi et al., 2010; Willis et al., 2010), and $18^{\circ} \mathrm{C}$ was used because it is close to the average water temperature of the streams from which the insects originate.

The values obtained by the assays were corrected by subtracting the final values from the initial reducing sugar values. The tests were carried out in quintuplicate $(\mathrm{N}=5)$. One unit of enzyme activity (U) was defined as $1 \mu \mathrm{M}$ reduced sugar released per minute. This activity was calculated using standard curves for the respective sugars. The specific activity was defined as the enzyme activity per mg protein in the digestive tract (U/mg digestive tract protein). The protein concentration in the digestive tract was quantified with the Coomassie Protein Assay (Pierce, USA) using bovine serum albumin as the standard.

The results of the enzyme assays conducted at the different temperatures and with different substrates are reported as means \pm standard deviation and were compared using analysis of variance (ANOVA), followed by the Tukey test $(\mathrm{P}<0.05)$.

\section{Isolation and quantification of bacteria}

The extraction of the digestive tract material from the larvae was performed according to Vasanthakumar et al. (2006). Ten individuals of each type of larva were used for the isolation and quantification of bacteria by adapting the method described by Geib et al. (2009). All intestinal tract extractions were performed in a laminar flow hood within $2 \mathrm{~h}$ following the collection of the insects from the trunks.

Serial dilutions were performed to $1: 1000$. From these dilutions, $100 \mu \mathrm{L}$ (homogenized) were spread on the basal medium [0.2 g/L yeast extract (Oxoid, England) and $15 \mathrm{~g} / \mathrm{L}$ 
No. 1 bacteriological agar (Oxoid)] with one of four different substrates as the main carbon source (5 g/L): 1) CMC (Sigma C5678), 2) beechwood xylan (Sigma X4252), 3) D-(+)-cellobiose (Sigma C7252, Slovakia), or 4) alkaline lignin (Aldrich 370 959, USA). These procedures were carried out in duplicate with the results showing only the mean. The dishes were incubated at $28^{\circ} \mathrm{C}$ for one week.

The colonies were categorized based on their size, elevation, margin, and pigmentation and counted. The cell types were identified by the Gram method. The mean quantity of isolated colonies and the weight of each digestive tract were used to determine the quantity of bacteria per gram of digestive tract (CFU/mg). For the acquisition of pure cultures, a single colony was isolated. Pure cultures were stored in trypticase soy broth (Difco, England) with $20 \%$ glycerol at $-20^{\circ} \mathrm{C}$ until required for use.

\section{Substrate degradation assays}

Colorimetric tests were performed on the stock cultures and individual dishes for the observation of activity halos. All tests were carried out in quintuplicate. The methylotrophic yeast Pichia pastoris was used as the positive control for CMC degradation, and the fungus Pleurotus sajor-caju was used as the positive control for xylan, cellobiose, and lignin degradation. The visualization of the degradation of CMC was performed using the Congo red method $(0.1 \%)$ (Theather and Wood, 1982). Dishes with isolated colonies were stained for $15 \mathrm{~min}$, drained, and washed three times with $1 \mathrm{M}$ sodium chloride. For xylan and cellobiose, a $\%$ iodine solution was used for $10 \mathrm{~min}$ (Williams, 1983). With this method, dark coloration is observed on the nondegraded substrate, whereas lighter coloration is observed in the halos produced by the degradation of the substrate. For the lignin degradation tests, solutions of $1 \%$ iron chloride $\left(\mathrm{FeCl}_{3}\right)$ and $1 \%$ potassium ferricyanide $\left[\mathrm{K}_{3} \mathrm{Fe}(\mathrm{CN})_{6}\right]$ were used in a proportion of 1:1 (Sundman and Nase, 1971). The dishes remained in the dark for $15 \mathrm{~min}$ to visualize the degradation; the non-degraded lignin was identified by a greenish-blue coloration and a yellowish-green region around and over the colony in cases in which the product was dephenolized.

Only the colonies that degraded a substrate underwent enzyme quantification and genetic identification tests. The bacterial enzyme activity was quantified based on the hydrolysis zone, which was calculated by determining the ratio between the diameter of the degradation zone and the diameter of the colony (called the enzymatic index) (Hankin and Anagnostakis, 1975). The enzymatic index is a fast, practical tool for the selection and comparison of the enzyme production of different microbial isolates. Values above 1.0 are indicative of enzyme secretion (Carrim et al., 2006). The ability of the colonies to degrade the other substrates was investigated. When positive, the enzymatic index was used to determine the quantity of bacteria that could potentially assist in the degradation processes.

\section{Genetic identification of bacteria}

The bacteria associated with the digestive tracts of the larvae that were capable of degrading the different types of substrate were identified by sequencing of the conserved $16 \mathrm{~S}$ rRNA region. The $16 \mathrm{~S}$ rRNA gene was amplified by colony polymerase chain reaction (PCR) with the primers 27F: 5'-AGAGTTTGATCMTGGCTCAG-3' (Giovannoni, 1991) and 1492R: 5'-GGTTACCTTGTTACGACTT-3' (Lane, 1991), which amplify a region of approximately 
$1.5 \mathrm{~kb}$. This procedure was carried out with an MJ Research PTC 100 Thermal Cycler using the following protocol: 1 cycle at $94^{\circ} \mathrm{C}$ for $5 \mathrm{~min} ; 35$ cycles of $94^{\circ} \mathrm{C}$ for $1 \mathrm{~min}, 50^{\circ} \mathrm{C}$ for $1 \mathrm{~min}$, and $72^{\circ} \mathrm{C}$ for $2 \mathrm{~min}$; and a final extension cycle at $72^{\circ} \mathrm{C}$ for $20 \mathrm{~min}$.

The amplification products were resolved on a 1\% agarose gel. A band of approximately $1.5 \mathrm{~kb}$ was cut from the gel and purified using the Wizard $^{\circledR}$ SV Gel and PCR Clean-Up System (Promega, USA), following manufacturer instructions, and the product obtained was subsequently quantified with a NanoDrop ND 1000 Spectrophotometer (Thermo Scientific, USA). The purified PCR product was sequenced with the flexible MegaBACE 1000, using the DYEnamic ET Dye Terminator kit (GE Healthcare) by following manufacturer instructions. The sequencing PCRs were performed using the initiating oligonucleotide 338F (5'-ACTCCTACGGGAGGCAGCAG-3') (Lane, 1991), which corresponds to the hypervariable V3 region of $16 \mathrm{~S}$ rRNA. The analysis of the sequences was performed with the Sequence Analyzer Base Caller Cimarron 3.12 software. Regions of low quality were removed (Phred $\leq 15$ ) using the dCAS program (Guo et al., 2009). Each $16 \mathrm{~S}$ rRNA bacterial sequence was compared to GenBank with the nucleotide Basic Local Alignment Search Tool (BLASTN) (July/2010) (Altschul et al., 1990) and Metagenome Rapid Annotation using Subsystem Technology (July/2010) (Meyer et al., 2008). The sequences generated by the present study were deposited in GenBank.

For phylogenetic analysis using the distance method (neighbor-joining) (Saitou and Nei, 1987), the 16S rRNA sequences that were obtained and other selected sequences taken from NCBI were aligned using the ClustalW tool of the MEGA version 5.0 program (Tamura et al., 2011). The adjustment of the sequence ends so that all of the sequences were aligned and had the same number of bases was performed using the MEGA version 5.0 program. Bootstrap analysis with 1000 replications was performed to calculate the statistical significance of the similarity between the sequences. The phylogenetic tree was generated with the distances calculated by the Kimura-2 parameter model, using the MEGA version 5.0 program.

\section{RESULTS}

\section{Enzyme assays}

The enzyme assays of the protein fluids extracted from the digestive tracts of the larvae indicated an incapacity for MCC degradation and a low capacity for CMC degradation. A mean activity of $1.24 \pm 2.40 \mathrm{U} / \mathrm{mg}$ protein was obtained from the digestive tracts of Stenochironomus 1 at $50^{\circ} \mathrm{C}$, and a mean activity of $1.52 \pm 2.48 \mathrm{U} / \mathrm{mg}$ protein was obtained from the digestive tracts of Stenochironomus 2 at $18^{\circ} \mathrm{C}$ (Figure 1).

In contrast, the assessment of the xylan degradation capacity demonstrated catalytic activity in the digestive tracts of both larval morphotypes. In Stenochironomus 1, the mean degradation activity was $29.61 \pm 10.29 \mathrm{U} / \mathrm{mg}$ protein from the digestive tract at $18^{\circ} \mathrm{C}$ and $336.42 \pm 79.31 \mathrm{U} / \mathrm{mg}$ at $50^{\circ} \mathrm{C}$. In Stenochironomus 2, the mean degradation activity was $22 \pm 3.88 \mathrm{U} / \mathrm{mg}$ protein from the digestive tract at $18^{\circ} \mathrm{C}$ and $116.85 \pm 49.53$ $\mathrm{U} / \mathrm{mg}$ at $50^{\circ} \mathrm{C}$ (Figure 1). No statistically significant differences were found between the mean values at $18^{\circ} \mathrm{C}(\mathrm{P}>0.05)$. However, significant differences were found between the morphotypes at $50^{\circ} \mathrm{C}(\mathrm{P}<0.05)$. 


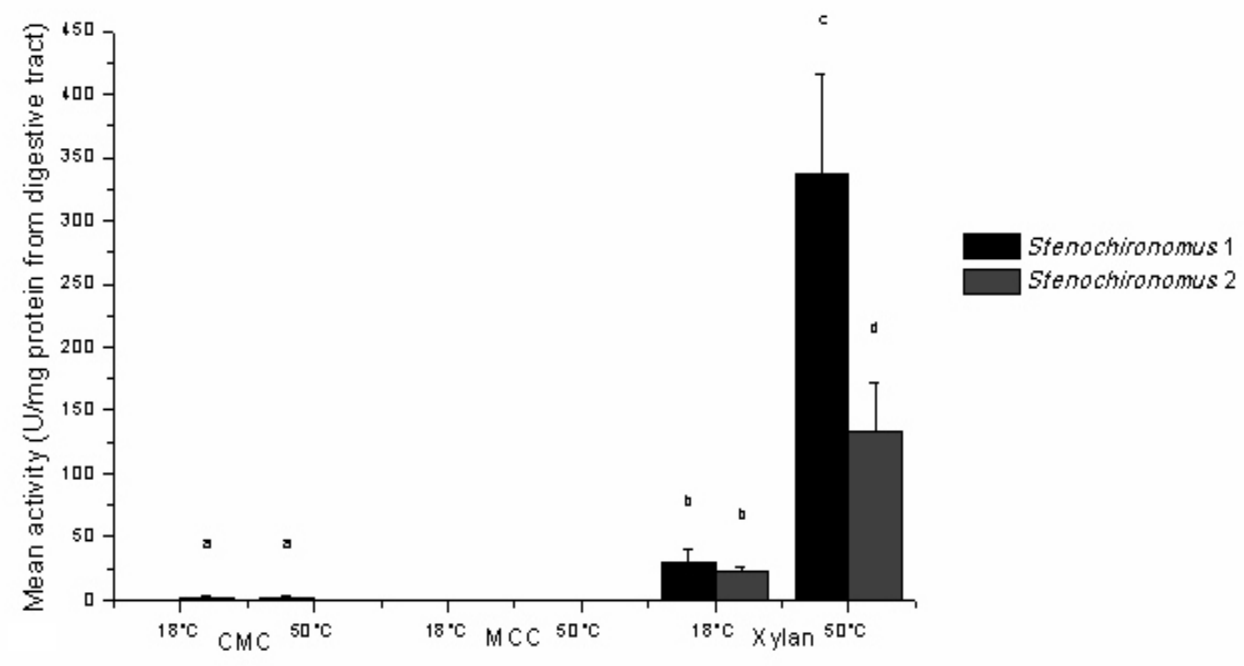

Figure 1. Results of specific cellulase and hemicellulase activity (U/mg protein) of intestinal digestive fluids of two morphotypes of Stenochironomus; one unit of enzyme activity $(\mathrm{U})$ is defined as $1 \mu \mathrm{M}$ reducing sugar released per minute at the specified temperature and $\mathrm{pH}$ 6.0; different letters denote statistically significant differences (Tukey test; $\mathrm{P}<0.05) . \mathrm{CMC}=$ carboxymethyl cellulose; $\mathrm{MCC}=$ microcrystalline cellulose.

\section{Bacterial evaluation}

Thirty-one morphotypes of bacterial colonies were isolated from the digestive tracts of the two types of larvae: 8 from Stenochironomus 1 and 23 from Stenochironomus 2 (Table 1). According to the colony halos, 19 morphotypes, i.e., 7 from Stenochironomus 1 and 12 from Stenochironomus 2, exhibited the capacity for degrading the substrate and were subsequently submitted to molecular identification. No bacterial colony capable of degrading lignin was found (Table 2).

Stenochironomus 1 larvae had a greater density of bacteria capable of degrading xylan $\left(1.75 \times 10^{5} \mathrm{CFU} / \mathrm{g}\right)$ and cellobiose $\left(5.09 \times 10^{4} \mathrm{CFU} / \mathrm{g}\right)$ and a lesser density of bacteria capable of degrading CMC $\left(1.63 \times 10^{4} \mathrm{CFU} / \mathrm{g}\right)$ in comparison with Stenochironomus 2, whose mean values were $1.39 \times 10^{4} \mathrm{CFU} / \mathrm{g}$ for xylan, $1.60 \times 10^{4} \mathrm{CFU} / \mathrm{g}$ for cellobiose, and $2.04 \times 10^{4}$ $\mathrm{CFU} / \mathrm{g}$ for CMC.

The analysis of the 16S rRNA sequences from the isolates by the neighbor-joining method indicated that there were five phylogenetic clusters (Figure 2). Seven of the isolates belonged to the $\gamma$-proteobacteria, whereas the Actinobacteria, Firmicutes, $\alpha$-proteobacteria, and $\beta$-proteobacteria comprised three isolates each.

Stenochironomus 2 larvae exhibited a greater richness of bacteria and enzymatic index values for all substrates that were degraded. Among the bacteria with the highest enzyme activities, those of the genus Sphingobium were found in both larval morphotypes. The bacteria of the genus Variovorax were capable of degrading CMC and cellobiose, and those of the genus Bacillus exhibited a high degradation capacity for the different substrates (Figure 3). 
R. Koroiva et al.

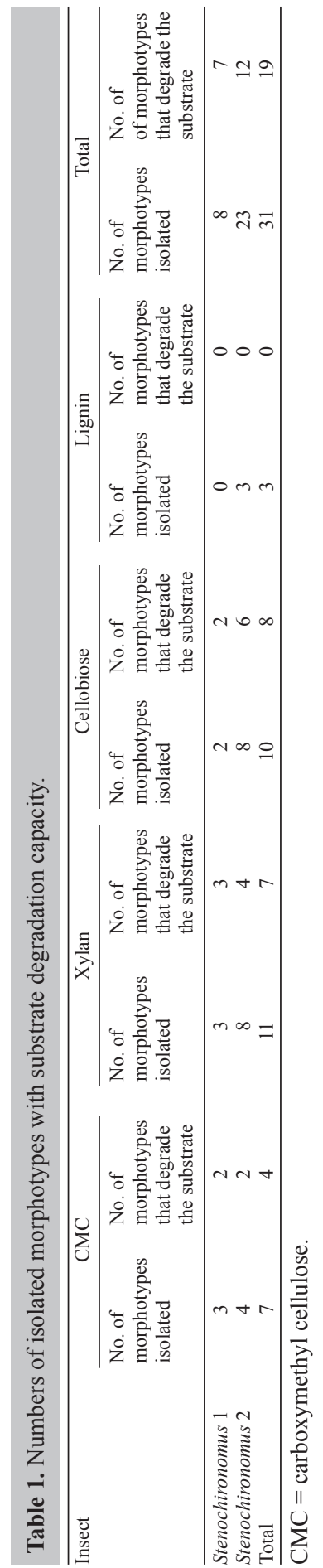




Table 2. Taxonomic affiliation and degradation capacities of bacteria found in the digestive tract of two larval
morphotypes of Stenochironomus.

$(+)=$ capacity for substrate degradation; $(-)=$ incapacity for substrate degradation.

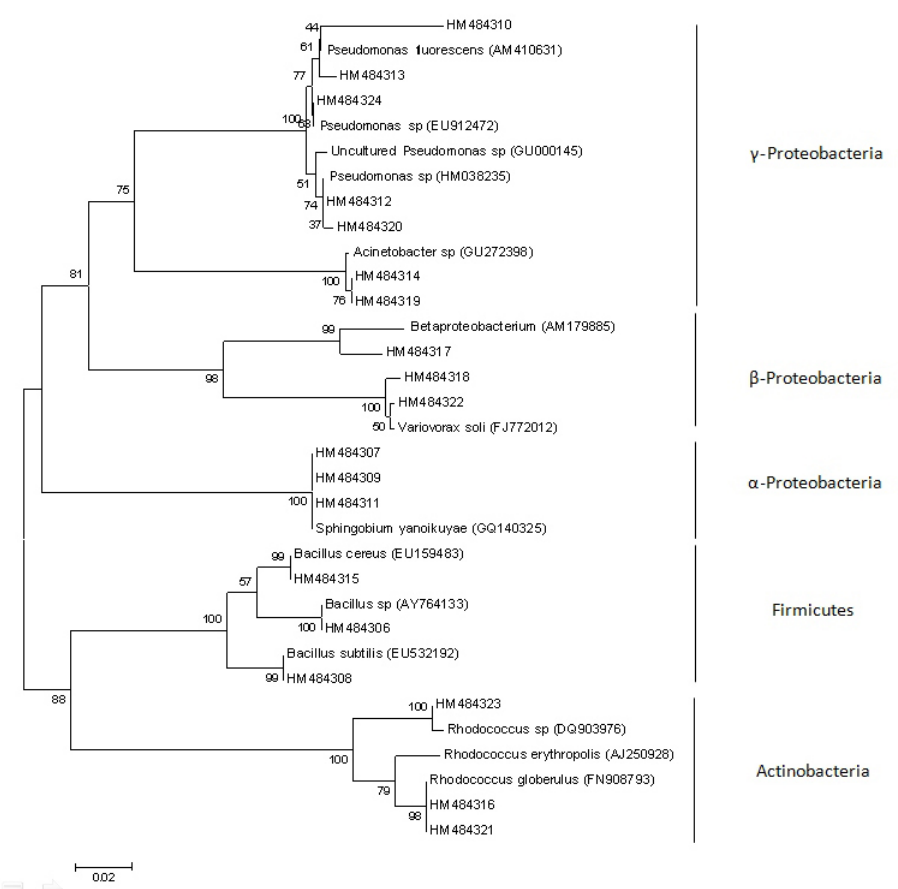

Figure 2. Unrooted phylogenetic tree based on sequences of the V3 region of the 16S rRNA-V3 gene obtained in the present study; the scientific names indicate the sequences obtained from GenBank. The tree was constructed using the neighbor-joining method, and the distances were calculated using the Kimura-2 method. The numbers associated with the inner nodes are bootstrap values (\%) obtained after 1000 replicates. The scale bar indicates a $2 \%$ divergence of sequences. 

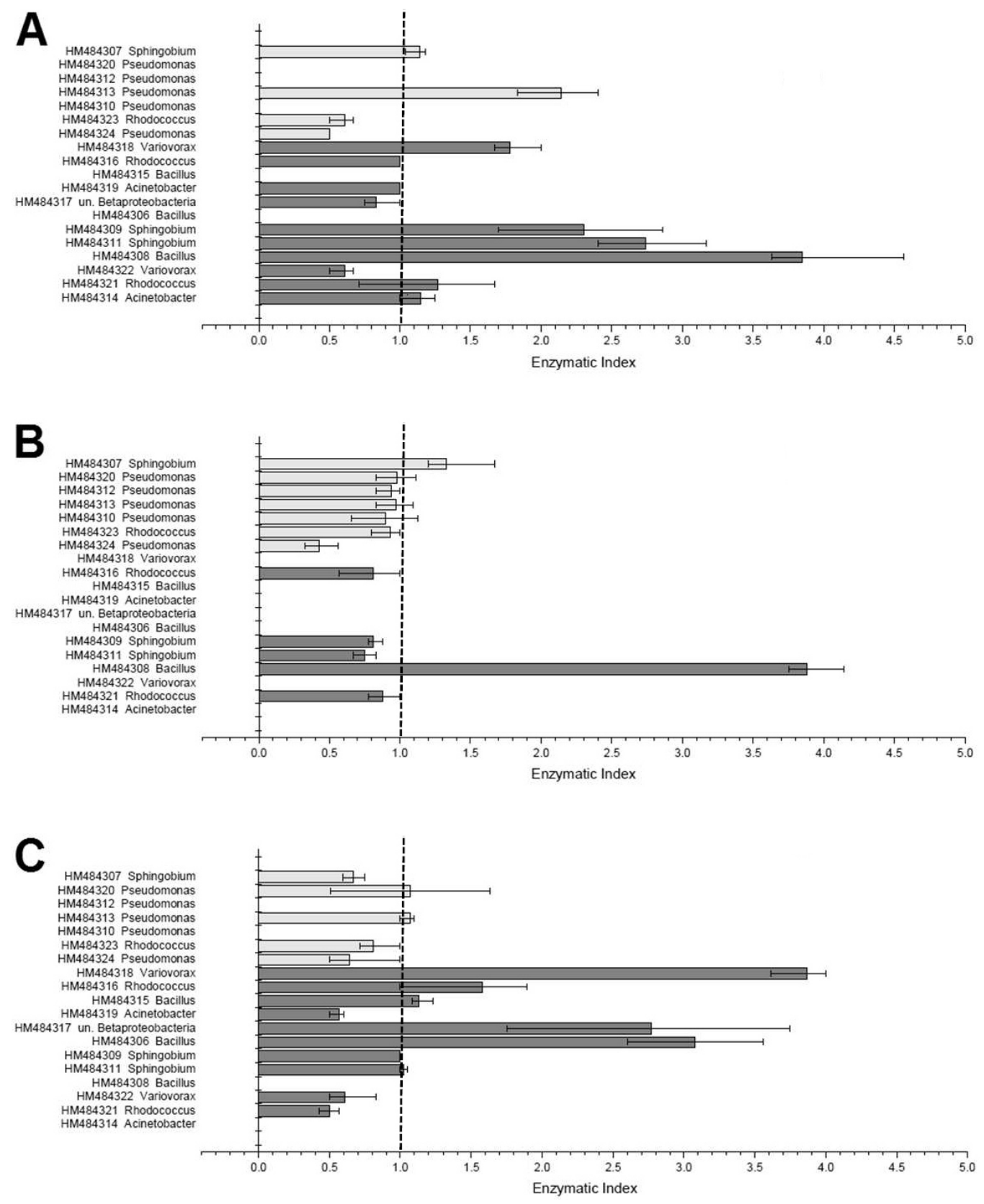

Figure 3. Enzyme activity results of the bacteria that were isolated from the digestive tracts of the two morphotypes of Stenochironomus (medium). Light gray bars = bacteria isolated from Stenochironomus 1 larvae; dark gray bars = bacteria isolated from Stenochironomus 2 larvae; thin bars = minimum and maximum values of the enzymatic index. A. Carboxymethyl cellulose; B. xylan; C. cellobiose. Values above 1.0 are indicative of enzyme excretion. 


\section{DISCUSSION}

In freshwater environments, whether lentic or lotic, in temperate or tropical regions, the degradation of submerged tree trunks by microorganisms is characterized by a loss of mass and growth that is restricted to the wet surface portions of the wood (Zare-Maivan and Sheare, 1988). This process is carried out by bacteria and fungi, especially by organisms of the division Ascomycota, in which the type of degradation, called soft rot, occurs through the action of exoenzymes on the secondary cell walls of the trunks to soften the outer layers of the wood through the breakdown of complex carbon compounds, such as cellulose and lignin. This degradation leads to the exposure of components of the fibrillary structure and makes simple carbon compounds available for consumption by other organisms, such as invertebrates (Simonis et al., 2008).

The results of the present study indicate that Stenochironomus larvae have a limited capacity for degrading cellulose but are able to degrade xylan. Together with ecological and physiological evidence, these findings allow us to infer that the preference for this type of substrate may be related to the type of microbial degradation and the availability of compounds provided by microorganisms.

According to Magoulick (1998), the large concentration of microorganisms and fungi on the wet outer layers of tree trunks is likely to be the reason for the occurrence of Stenochironomus larvae on trunks of soft consistencies. Regardless if the digestion and assimilation of carbon of microbial origin occurs in the larvae of chironomids (Pinder, 1986), the activity of fungi and bacteria is important for the cycling of carbon in freshwater ecosystems through the production of enzymes that degrade lignocellulosic materials (Simonis et al., 2008). The nearly neutral intestinal $\mathrm{pH}$ in the digestive tracts of chironomid larvae (Frouz et al., 2007) provides favorable conditions for microbial growth and enzyme activity, since a neutral $\mathrm{pH}$ allows the growth of the majority of bacteria and fungi, including cellulolytic species (Landaud et al., 1995). Thus, the direct supply of simple carbon compounds in wood, the exposure of fibrillary compounds, such as xylan, which is digested by the insect, and the physiological conditions of the digestive tract that allow microbial growth and enzyme activity are factors that must contribute to the supply of energy compounds for Stenochironomus larvae.

Although the capacity for cellulose degradation is common among terrestrial mining insects, Zverlov et al. (2003) reported that the larvae of Rhagium inquisitor (Coleoptera: Cerambycidae), which is a beetle that mines tree trunks in Eurasia, are incapable of degrading cellulose. The larvae of this species have a diversity of enzymes in their digestive tracts that are capable of degrading other polysaccharides and oligosaccharides, which may be their source of carbohydrates. While the use of cellulose and xylan was investigated in the present study, the hypothesis that other carbohydrates could be used should also be considered for Stenochironomus larvae.

A number of studies have addressed the capacity of mining insects in hydrolyzing cellulose and hemicellulose (e.g., Martin et al., 1981; Oppert et al., 2010). However, the different methods employed hinder the comparison of results with the present study. Another aspect that impedes the comparison of results is the temperature established for the determination of enzyme activity because degradation is generally greater at temperatures higher than those in which the insects live, which was demonstrated in the present study (e.g., Martin et al., 1981). In comparison with the study carried out by Shi et al. (2010), in which the method for determining reducing sugars was similar to the one used in the present study, the values for the Stenochironomus larvae were lower than those reported for the larvae of terrestrial beetles 
(about $284 \mu \mathrm{M} \cdot \mathrm{mg}^{-1} \cdot \mathrm{min}^{-1}$ for $\mathrm{CMC}$ and $4800 \mu \mathrm{M} \cdot \mathrm{mg}^{-1} \cdot \mathrm{min}^{-1}$ for xylan; $\mathrm{pH} 7.0$ at $50^{\circ} \mathrm{C}$ ), but close to results reported for the phytophagous silkworm (about $74 \mu \mathrm{M} \cdot \mathrm{mg}^{-1} \cdot \mathrm{min}^{-1}$ for CMC and $600 \mu \mathrm{M} \cdot \mathrm{mg}^{-1} \cdot \mathrm{min}^{-1}$ for xylan; $\mathrm{pH} 7.0$ at $50^{\circ} \mathrm{C}$ ).

Although not performed individually, as in previous studies addressing the characterization of potential resilient species in the digestive tract (Delalibera Jr. et al., 2005, 2007), the bacterial quantification used in the present study allows comparison with values reported for other insects. The larvae of cockroaches (Cruden and Markovetz, 1979) and termites (Wenzel et al., 2002) have bacterial counts 100- to 1000 -fold higher. However, the results of the present study are close to those reported for the larvae of beetles. For example, by assessing the culture-dependent bacterial community of Anoplophora glabripennis, an insect that is believed to utilize microbial exoenzymes, Geib et al. (2009) reported a mean of $2.6 \times 10^{4} \mathrm{CFU} / \mathrm{g}$ in the intestine of this insect on CMC-selective media, which is similar to the quantity found in the Stenochironomus larvae in the present study.

The results of the analysis of the bacterial species that were isolated from the digestive tracts of Stenochironomus larvae were similar to those for other insects that are capable of degrading wood components. The five phylogenetic clusters that were established in the present study have also been reported in the digestive tracts of other xylophagous and phytophagous insects (e.g., Vasanthakumar et al., 2006; Park et al., 2007). For example, a larger proportion of cultivable isolates of $\gamma$-proteobacteria have also been reported in different species of beetles (Park et al., 2007). At the genus level, Bacillus and Pseudomonas are recognized for their ability to degrade biopolymers (Gilbert and Hazlewood, 1993) and are common in the digestive tracts of saproxylic insects, such as tipulids, termites, and cerambycid beetles (Moore, 1972; Wenzel et al., 2002; Cook et al., 2007; Park et al., 2007). In addition to these bacteria, Sphingobium yanoikuyae was demonstrated in the present study to be present in both types of larvae analyzed. The high degree of versatility in the catabolism of biopolymers including cellulose (Delalibera Jr. et al., 2005), and its occurrence in the digestive tracts of Saperda vestita (Coleoptera: Cerambycidae) larvae observed in different periods and locations, lends support to the hypothesis put forth by Delalibera Jr. et al. (2005) that this bacterium participates in the degradation of wood ingested by this beetle.

During the course of the present study, a number of attempts at depuration and the isolated breeding of Stenochironomus larvae were made using methods described for other species of the family Chironomidae without success. This limited the possibility of generating further information about the endogenous enzymatic capacity, microorganism resilience, and bacterial importance in the digestive tracts of the larvae studied.

It should be stressed that this is the first report of hydrolytic bacteria and enzymes that act on lignocellulosic compounds in the digestive tracts of mining chironomids.

The results of the present study demonstrate that the digestive tracts of Stenochironomus larvae have a lesser capacity for cellulose degradation in comparison with xylan degradation. The degradation of wood by microorganisms is believed to assist in the use of this resource either by providing degraded carbon compounds or by exposing the fibers to degradation. Bacteria that are capable of degrading cellulosic compounds were detected in the intestinal tracts of Stenochironomus larvae. The genera and mean numbers of bacteria were similar to those reported in other insects that benefit from the production of exoenzymes. These findings indicate that there is a microbial contribution to the digestion of wood within the digestive tracts of Stenochironomus larvae. 


\section{ACKNOWLEDGMENTS}

Research supported by the Brazilian agency CAPES with a grant awarded to the first author and by the Postgraduate Program in Ecology and Natural Resources of Universidade Federal de São Carlos (Brazil). The authors are grateful to the following people: Francisco Valente Neto, Daniel Gonçalves da Fonseca, Fabio Toshiro, Rogério Libório, and Gustavo Rincon Mazão for assistance with the collections; Wagner Chiba de Castro, Dr. Irineu Bianchini Júnior, and Dr. Marcela Bianchessi da Cunha-Santino for assistance with the biochemical analyses; Dr. Italo Delalibera Jr. (ESALQ-USP) and Janaina Lamezon for assistance in the assessments of substrate degradation by the bacteria; and Darlan Gonçalves Nakayama and Danilo Elton Evangelista for assistance with the genetic analyses.

\section{REFERENCES}

Altschul SF, Gish W, Miller W, Myers EW, et al. (1990). Basic local alignment search tool. J. Mol. Biol. 215: 403-410. Baker JH and Brandnam LA (1976). The role of bacteria in the nutrition of aquatic detritivores. Oecologia 24: 95-104.

Brune A (2006). Symbiontic Associations Between Termites and Prokaryotes. The Prokaryotes: Symbiotic Associations, Biotechnology, Applied Microbiology (Dworkin M, Falkow S, Rosenberg E, Schleifer KH, et al., eds.). Volume 1. Springer, New York.

Carrim AJI, Barbosa EC and Vieira JDG (2006). Enzymatic activity of endophytic bacterial isolates of Jacaranda decurrens Cham. (Carobinha-do-campo). Braz. Arch. Biol. Tech. 49: 353-359.

Cook DM, DeCrescenzo HE, Upchurch R and Peterson JB (2007). Isolation of polymer-degrading bacteria and characterization of the hindgut bacterial community from the detritus-feeding larvae of Tipula abdominalis (Diptera: Tipulidae). Appl. Environ. Microbiol. 73: 5683-5686.

Cruden DL and Markovetz AJ (1979). Carboxymethyl cellulose decomposition by intestinal bacteria of cockroaches. Appl. Environ. Microbiol. 38: 369-372.

Delalibera I Jr, Handelsman J and Raffa KF (2005). Contrasts in cellulolytic activities of gut microorganisms between the wood borer, Saperda vestita (Coleoptera: Cerambycidae), and the bark beetles, Ips pini and Dendroctonus frontalis (Coleoptera: Curculionidae). Environ. Entomol. 34: 541-547.

Delalibera I Jr, Vasanthakumar A, Burwitz BJ, Schloss PD, et al. (2007). Composition of the bacterial community in the gut of the pine engraver, Ips pini (Say) (Coleoptera) colonizing red pine. Symbiosis 43: 97-104.

Frouz J, Lobinske RJ, Yaqub A and Ali A (2007). Larval gut pH profile in pestiferous Chironomus crassicaudatus and Glyptotendipes paripes (Chironomidae: Diptera) in reference to the toxicity potential of Bacillus thuringiensis serovar israelensis. J. Am. Mosq. Control Assoc. 23: 355-358.

Geib SM, Jimenez-Gasco MM, Carlson JE, Tien M, et al. (2009). Effect of host tree species on cellulase activity and bacterial community composition in the gut of larval Asian longhorned beetle. Environ. Entomol. 38: 686-699.

Gilbert HJ and Hazlewood GP (1993). Bacterial cellulases and xylanases. J. Gen. Microbiol. 139: 187-194.

Giovannoni SJ (1991). The Polymerase Chain Reaction. In: Nucleic Acid Techniques in Bacterial Systematic (Stackebrandt E and Goodfellow M, eds.). John Wiley and Sons, New York, 177-203.

Guo Y, Ribeiro JM, Anderson JM and Bour S (2009). dCAS: a desktop application for cDNA sequence annotation. Bioinformatics 25: 1195-1196.

Hankin L and Anagnostakis SL (1975). The use of solid media for detection of enzyme production by fungi. Mycologia 67: 597-607.

Johnson RK, Boström B and van de Bund WJ (1989). Interactions between Chironomus plumosus (L) and the microbial community in surficial sediments of a shallow eutrophic lake. Limnol. Oceanogr. 34: 992-1003.

Kaufman MG, Pankratz HS and Klug MJ (1986). Bacteria associated with the ectoperitrophic space in the midgut of the larva of the midge Xylotopus par (Diptera: Chironomidae). Appl. Environ. Microbiol. 51: 657-660.

Landaud S, Piquerel P and Pourquié J (1995). Screening for bacilli producing cellulolytic enzymes active in the neutral $\mathrm{pH}$ range. Lett. Appl. Microbiol. 21: 319-321.

Lane DJ (1991). 16S/23S rRNA Sequencing. In: Nucleic Acid Techniques in Bacterial Systematic (Stackebrandt E and Goodfellow M, eds.). John Wiley and Sons, New York, 115-175.

Magoulick DD (1998). Effect of wood hardness, condition, texture and substrate type on community structure of stream 
invertebrates. Am. Midl. Nat. 139: 187-200.

Martin MM (1983). Cellulose digestion in insects. Comp. Biochem. Physiol. 75: 313-324.

Martin MM, Kukor JJ, Martin JS, Lawson DL, et al. (1981). Digestive enzymes of larvae of three species of caddisfiies (Trichoptera). Insect Biochem. 11: 501-505.

Meyer F, Paarmann D, D’Souza M, Olson R, et al. (2008). The metagenomics RAST server - a public resource for the automatic phylogenetic and functional analysis of metagenomes. BMC Bioinformatics 9: 386.

Moore GE (1972). Microflora from the alimentary tract of healthy southern pine beetles, Dendroctonus frontalis (Scolytidae), and their possible relationship to pathogenicity. J. Invertebr. Pathol. 19: 72-75.

Oppert C, Klingeman WE, Willis JD, Oppert B, et al. (2010). Prospecting for cellulolytic activity in insect digestive fluids. Comp. Biochem. Physiol. B Biochem. Mol. Biol. 155: 145-154.

Park DS, Oh HW, Jeong WJ, Kim H, et al. (2007). A culture-based study of the bacterial communities within the guts of nine longicorn beetle species and their exo-enzyme producing properties for degrading xylan and pectin. $J$. Microbiol. 45: 394-401.

Pinder LCV (1986). Biology of freshwater Chironomidae. Ann. Rev. Entomol. 31: 1-23.

Rouf MA and Rigney MM (1993). Bacterial florae in larvae of the lake fly Chironomus plumosus. Appl. Environ. Microbiol. 59: 1236-1241.

Saitou N and Nei M (1987). The neighbor-joining method: a new method for reconstructing phylogenetic trees. Mol. Biol. Evol. 4: 406-425.

Shi WB, Ding SY and Yuan JS (2010). Comparison of insect gut cellulase and xylanase activity across different insect species with distinct food sources. Bioenergy Res. 4: 1-10.

Simonis JL, Raja HA and Shearer CA (2008). Extracellular enzymes and soft rot decay: Are ascomycetes important degraders in fresh water? Fungal Divers. 31: 135-146.

Sinsabaugh RL, Linkins AE and Benfield EF (1985). Cellulose digestion and assimilation by three leaf-shredding aquatic insects. Ecology 66: 1464-1471.

Sundman V and Nase L (1971). A simple plate test for direct visualization of biological lignin degradation. Pap. Timber 53: 65-71.

Tamura K, Peterson D, Peterson N, Stecher G, et al. (2011). MEGA5: Molecular Evolutionary Genetics Analysis using maximum likelihood, evolutionary distance, and maximum parsimony methods. Mol. Biol. Evol. 28: 2731-2739.

Teather RM and Wood PJ (1982). Use of Congo red-polysaccharide interactions in enumeration and characterization of cellulolytic bacteria from the bovine rumen. Appl. Environ. Microbiol. 43: 777-780.

Vasanthakumar A, Delalibera I Jr, Handelsman J, Klepzig KD, et al. (2006). Characterization of gut-associated bacteria in larvae and adults of the southern pine beetle, Dendroctonus frontalis Zimmermann. Environ. Entomol. 35: 17101717.

Wenzel M, Schonig I, Berchtold M, Kampfer P, et al. (2002). Aerobic and facultatively anaerobic cellulolytic bacteria from the gut of the termite Zootermopsis angusticollis. J. Appl. Microbiol. 92: 32-40.

Williams AG (1983). Staining reactions for the detection of hemicellulose-degrading bacteria. FEMS Microbiol. Lett. 20: 253-258.

Willis JD, Klingeman WE, Oppert C, Oppert B, et al. (2010). Characterization of cellulolytic activity from digestive fluids of Dissosteira carolina (Orthoptera: Acrididae). Comp. Biochem. Physiol. B Biochem. Mol. Biol. 157: 267-272.

Zare-Maivan H and Shearer CA (1988). Extracellular enzyme production and cell wall degradation by freshwater lignicolous fungi. Mycologia 80: 365-375.

Zverlov VV, Höll W and Schwarz WH (2003). Enzymes for digestion of cellulose and other polysaccharides in the gut of longhorn beetle larvae, Rhagium inquisitor L. (Col., Cerambycidae). Int. Biodeter. Biodegr. 51: 175-179. 